\title{
Enhancing Self Efficacy Of Prolanis Group On Self Assessment Of Diabetic Foot Early Detection Based On Health Belief Model Theory nd Bandura's Self Efficacy
}

\author{
Didik Susetiyanto Atmojo*, Heny Kristanto, Hengky Irawan \\ Dharma Husada Kediri Nursing Academy, Indonesia \\ *atmojodidik@gmail.com
}

\begin{abstract}
Diabetes Mellitus (DM) complications are serious problems for patients and their families. One of the chronic complications in diabetes mellitus patients is diabetic foot infection/injury. Diabetic foot infection/injury is the main cause of patients coming to health services or hospitals. According to Litzemen, diabetic patients are very at risk of foot injury. If the patient knows the risk factors and how to check or detect early injury to the leg, it is hoped that the patient will be spared or the risk of diabetic foot infection can be reduced. Examination of the feet wass done by recognizing the shape of the foot disorder, assessing the neuropathy status and pulsation / vascular status. With Self Efficacy, patients will increase their confidence and ability to detect the risk of diabetic foot injury early. The purpose of this study was to improve Self Efficacy on the ability to detect the risk of diabetic foot injury.

The research design used was pre-experimental research with a one group pre-post test design approach. Respondents of this study were the Clinic Prolanis Group dr. Chreslina Subagyo, Kediri City who met the inclusion criteria. Collecting data with clinical questionnaire sheet self-efficacy skills in order to determine the increase in self-efficacy, the ability to detect early risk factors for diabetic foot injury and for the risk of diabetic foot incidence using the diabetic foot early detection assessment format.

Data analysys used the Wilcoxon statistical test with a significance level of $\alpha=0.05$. Based on the Wilcoxon test above, the $\mathrm{p}$ value $=0.000$, which means that action given caused a changed or increased in a person's self-assessment related to the risk of DM foot injury.

This study revealed that the potential impact of self-efficacy, outcome expectations, communicative should be considered in the education program for patients with diabetes. it found self-efficacy to be the most important predictor of diabetes self-care. Therefore, the use of self-efficacy theory when designing patient education interventions could enhance diabetes self-care.
\end{abstract}

Keywords : Self Efficacy, Diabetic Foot, Self Assesment 


\section{STRADA Jurnal Ilmiah Kesehatan}

DOI: $10.30994 /$ sjik.v9i2.409

ISSN: 2252-3847 (print); 2614-350X (online)

Vol.9 No.2 November 2020 Page.950-953

\section{BACKGROUND}

Diabetes Mellitus (DM) is a global problem in health care. In developing countries, a chronic complication that often occurs in diabetes mellitus patients is diabetic foot infection (KDI). Diabetic foot is one of the chronic complications of diabetes. If not treated properly, diabetic feet can easily get injured and quickly develop into worse complications. One of the efforts to manage diabetes feet is to detect the risk of diabetes feet early. With Self Efficacy, it is expected that the patient's ability, knowledge and independence will increase in knowing the risk of diabetic foot. Self efficacy is an important predictor of self-care for diabetes patients so that the use of self-efficacy theory in designing patient education interventions can improve diabetes self-care (Mahnoush Reisi, 2016 ). A high increase in self-efficacy affects blood sugar control, medication adherence and self-care behavior (Rebekkah J Walker, 2014) The role of nurses as a Health Educator (health education), especially in the care of diabetic feet, is needed, especially in examining the feet of someone who has a risk of suffering from diabetes mellitus. suppressed the number of events. The Pronalist group is part of the community who has experience and has routine activities in preventing complications of DM by exercising and checking blood sugar. In providing nursing care to patients in the Pronalist group, in addition to providing health education, nurses teach and provide simple examples of methods for early detection of diabetic foot as a preventive and promotive action in preventing diabetic foot.

\section{METHODS}

The research design used was pre-experimental research with a one group pre-post test design approach. Respondents of this study were the Prolanis Group of dr. Chreslina Subagyo clinic who met the inclusion criteria. The population studied were all members of the Prolanis group who suffered from type I and type II

With total number 40 participants The sampling technique used total sampling. Collecting data with clinical questionnaire sheet self-efficacy skills in order to determine the increase in self-efficacy, the ability to detect early risk factors for diabetic foot injury and for the risk of diabetic foot incidence using the diabetic foot early detection assessment format.

Research was taken at dr. Chreslina Subagyo clinic for 1 months ( june 2020) by adhering to the COVID-19 health protocol.

\section{RESULTS}

Characteristic of respondents

Tabel 1 Respondent characteristic

\begin{tabular}{|c|l|c|c|}
\hline \multirow{2}{*}{ No } & \multicolumn{2}{|}{ Respondents characteristic } & \multicolumn{2}{|c|}{ number } \\
\cline { 3 - 4 } & & Total & $\%$ \\
\hline 1. & Gender & 19 & $47,5 \%$ \\
& a. Male & 21 & $52,5 \%$ \\
& b. Female & & \\
\hline 2. & Length of suffering DM & 13 & $32,5 \%$ \\
& a. 10 yrs & 27 & $67,5 \%$ \\
b.>10yrsEver & & \\
\hline 3. & Work status & $\mathbf{1 3}$ & $\mathbf{3 2 , 5 \%}$ \\
\hline
\end{tabular}




\section{STRADA Jurnal Ilmiah Kesehatan}

DOI: $10.30994 /$ sjik.v9i2.409

ISSN: 2252-3847 (print); 2614-350X (online)

Vol.9 No.2 November 2020 Page.950-953

\begin{tabular}{|l|l|c|c|}
\hline & b.housewife / & 27 & $67,5 \%$ \\
\hline 4. & Age & & \\
& a. $40-50$ & 1 & $2,5 \%$ \\
& b.50-60 & 25 & $62,5 \%$ \\
& c. 60-70 & 14 & $35 \%$ \\
\hline
\end{tabular}

Tabel 2 Risk of developing diabetic foot

\begin{tabular}{|l|c|c|}
\hline \multirow{2}{*}{ Level } & \multicolumn{2}{|c|}{} \\
\cline { 2 - 3 } a. high & $\sum$ & $\%$ \\
b. Medium & 5 & 12,5 \\
c. low & 16 & 40 \\
\hline
\end{tabular}

Table 3. result pre and post intervention

\begin{tabular}{|c|l|c|c|c|c|}
\hline \multirow{2}{*}{ No } & \multicolumn{1}{|c|}{ Category } & \multicolumn{2}{c|}{ Pre Intervention } & \multicolumn{2}{c|}{ Post Interventiosn } \\
\cline { 3 - 6 } & & Total & $\%$ & Total & $\%$ \\
\hline 1. & Self Efficacy & & & & \\
& a. High & 0 & 0 & 39 & 97,5 \\
& b. Medium & 40 & 100 & 1 & 2,5 \\
& c. Low & 0 & 0 & 0 & 0 \\
\hline 2. & Self Assesment & & & & \\
& a. Good & 6 & 15 & 26 & 65 \\
& b. Enough & 24 & 60 & 14 & 35 \\
& c. Less & 10 & 25 & 0 & 0 \\
\hline
\end{tabular}

On table 3 shown that there were significant diferrences result of self efficacy on self assesment between pre and post intervention.

\section{Wilcoxon Signed Ranks Test}

Test Statisticsb

\begin{tabular}{|l|r|}
\hline & Post Self Assesment - Pre Self Assesment \\
\hline$Z$ & $-4,817^{\mathrm{a}}$ \\
Asymp. Sig. (2- &, 000 \\
tailed) & \\
\hline
\end{tabular}

a. Based on negative ranks.

b. Wilcoxon Signed Ranks Test

Data analysys used the Wilcoxon statistical test with a significance level of $\alpha=0.05$. Based on the Wilcoxon test above, the $\mathrm{p}$ value $=0.000$, means that action given caused a changed or increased in a person's self-assessment related to the risk of DM foot injury. Enhancing self efficacy effect on increasing self assesment of diabetic foot early detection

\section{DISCUSSION}

This study revealed that the potential impact of self-efficacy, outcome expectations, communicative should be considered in the education program for patients with diabetes. it found self-efficacy to be the most important predictor of diabetes self-care. Therefore, the 


\section{STRADA Jurnal Ilmiah Kesehatan}

DOI: $10.30994 /$ sjik.v9i2.409

ISSN: 2252-3847 (print); 2614-350X (online)

Vol.9 No.2 November 2020 Page.950-953

use of self-efficacy theory when designing patient education interventions could enhance diabetes self-care. It is essential that health care providers assess patient self efficacy levels to tailor health-related information.This would fully inform patients and promote empowerment rather than simple compliance.

\section{CONCLUSION}

This study revealed that the potential impact of self-efficacy, outcome expectations, communicative should be considered in the education program for patients with diabetes. it found self-efficacy to be the most important predictor of diabetes selfcare. Therefore, the use of self-efficacy theory when designing patient education interventions could enhance diabetes self-care.

\section{REFERENCES}

Aziz Nather, 2004, The Diabetic Foot, Word Scientific, Singapore

Carville K, 2007, Wound Care Manual, fifth edition, reprinted 2007, by the Silfer Cain Nursing Assosiation, Australia

Dono N,

http://www.medistra.com/index.php?option=com_content\&view=article\&id=175,

diunduh 1 Januari 2018

Gitarja W S, 2008, Perawatan Luka Diabetes, Wocare Bogor, Indonesia

Gitarja W S, 2014, Perawatan Luka, Wocare Center, Bogor

Mahnoush reisi, Firoozeh Mostafavi, Homamodin Javadzade, Behzad Mahaki, Elahe Tavassoli, Gholamreza Sharifirad (2016)Impact of Health Literacy, Self-efficacy, and Outcome Expectations on Adherence to Self-care Behaviors in Iranians with Type 2 Diabetes, Oman Med J Jan; 31(1): 52-59

Rebekkah J. Walker, Brittany L. Smalls, Melba A. Hernandez-Tejada, Jennifer A. Campbell, Leonard E. Egede Effect of Diabetes Self-Efficacy on Glycemic Control, Medication Adherence, Self-Care Behaviors, and Quality of Life in a Predominantly Low-Income (2014), Minority Population, Published by Ethnicity \& Disease, Inc vol 24 no 3

Sumpio, Stephen, Blume, 2005, Etiology and Management of Foot Ulcerations, The Mc Graw Hill Companies, Singapore

Shankhdar K, Shankhdar LK, Shankhdar U, Diabetic foot care in the land of no podiatrists,South Amerika, WCET Jurnal, 2008 March 1;28: 20-23

Ostrow B, Woo Y K, Sibbald R G, 2010, WCET Journal,The Guyana Diabetic Foot Project: Reducing amputations and improving diabetes care in Guyana, volume 30, Number 4, December, page:28-32

Ramaiah S, 2008, Cara mengetahui gejala diabetes dan mendeteksi sejak dini, Penerbit BIP PERKENI, 2006, Konsensus Pengelolaan dan Pencegahan Diabetes Mellitus Tipe 2 Indonesia,

PutriH,http://www.perawatluka.com/perawatan-kaki-diabetik/ diakses 1 Januari 2018

Citra Windani Mambang Sari, Hartiah Haroen, Nursiswati, Pengaruh Program Edukasi Perawatan Kaki Berbasis Keluarga terhadap Perilaku Perawatan Kaki pada Pasien Diabetes Melitus Tipe 2, JKP-Volume 4 Nomor 3 Desember 2016

Dhora Sihombing Jurnal. Gambaran Perawatan Kaki dan sensasi Sensorik kaki pada

Pasien Diabetus Melitus Tipe 2 di poliklinik DM Di RSUD Bandung, unpad.ac.id/ejournal/article/view/677, vol 1 no 1, 2012. 